\title{
電池用セパレータ
}

\section{Battery Separators}

\section{1. はじめに}

1990 年代初期に商品化されたニッケル水素電池やリチ ウムイオン電池は ${ }^{1-4)}$ 、軽量・コンパクトで、かつ、クリー ンなことから、携帯電話やノート型パソコンなどのモバイ ル機器に広く採用され、わが国の全電池販売の半分近くを 占めるまでに成長してきた(図 1)。世界では年間 5 億台の 携帯電話が製造販売され、すでに 13 億人が利用しており、 二次電池がなくてはならないものになっている。宇宙から 情報通信技術を支える人工衛星においても、その寿命を決 めるのは電池寿命であることはよく知られている。最近で は、デジタルカメラや電動自転車、コードレス掃除機、口 ボット、バックアップ用電源、乾電池代替など、二次電池 の利用分野が拡大している。また、1996 年ごろから、こ れら二次電池を利用した高性能電気自動車の商品化が、 1997 年からはハイブリッド自動車の商品化が開始され、 次世代クリーン自動車の分野でも二次電池の利用が進んで いる。2002 年からは水素エネルギー社会への第一歩とし てハイブリッド型水素燃料電池自動車の販売も開始された。

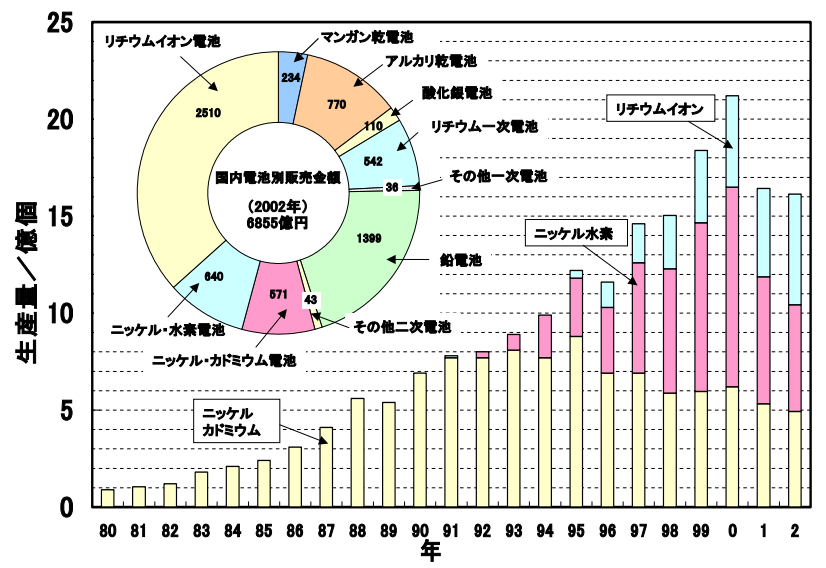

図 1 小型二次電池の生産個数の推移

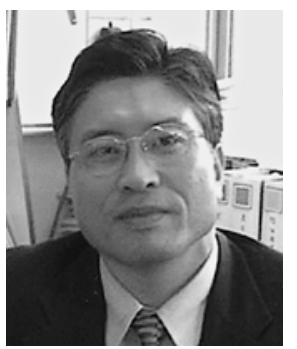

TETSUO SAKAI

独産業技術総合研究所ユビキタスエネル ギー研究部門 電池システム連携研究体 長、神戸大学 併任教授

T563-8577 大阪府池田市緑丘 1-8-31 Tel : 072-751-9611 Fax : 072-751-9623 E-mail : sakai-tetsuo@aist.go.jp 〈尃門〉電池材料 〈趣味〉水泳
このように電池技術は、21 世紀の情報通信技術やエネル ギー環境技術を支えるキーデバイスと考えられ、電池高性 能化の激しい開発競争が行われている。

しかし、電池の高エネルギー密度化が進展するに伴い、 安全性や信頼性の確保が不可欠となり、正極と負極を隔離 する脇役に過ぎなかったセパレータの重要性が大きくクロー スアップされている5 ${ }^{5-8)}$ 。ニケル水素電池では 100 ミクロ ン程度の表面処理ポリオレフィン系不織布が、リチウムイ オン電池では 10 ミクロン程度のポリオレフィン系微多孔 フィルムが利用されているが、この薄膜の中に多様な機能 を付与すべく、材料技術を駆使した研究開発が行われてき た ${ }^{9-19}$ 。本稿では、電池素材に扔ける機能性セパレー夕に 関して、開発動向と展望について紹介したい。

\section{2. ニッケル水素電池用セパレータ}

\section{1 反応機構とセパレータ}

この電池は、図 2 に示すように水素吸蔵合金負極、水酸 化ニッケル正極、不織布セパレータにより構成され、これ に濃アルカリ電解液を含浸させて電池缶に密閉化した構造 となっている。過充電時に二ッケル正極より発生した酸素 を、セパレータを介して合金負極上で水素と再結合させて 水に還すことによって、密閉化を実現している。この場合、

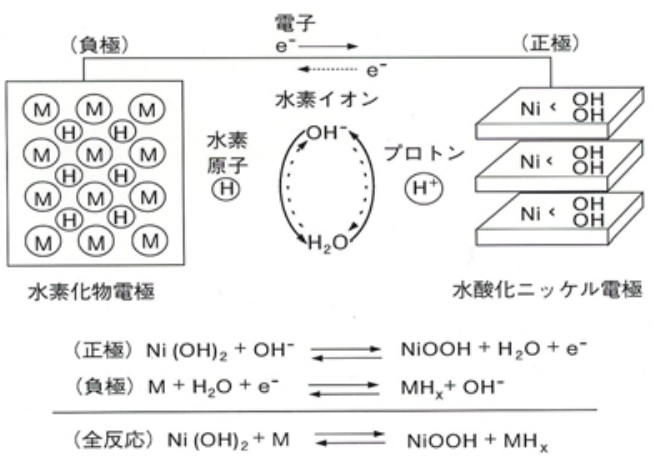

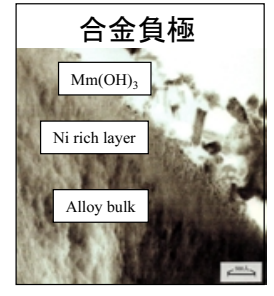

（合金粒子断面）

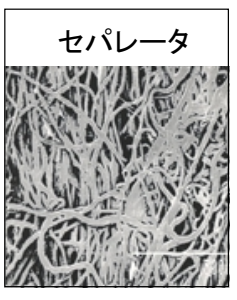

(PP不織布)

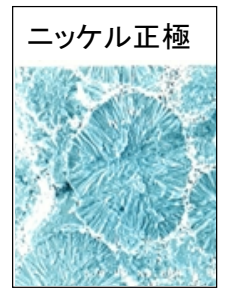

（球状水酸化ニッケル）
図 $2 \mathrm{Ni}-\mathrm{MH}$ 電池の反応機構と構成材料 

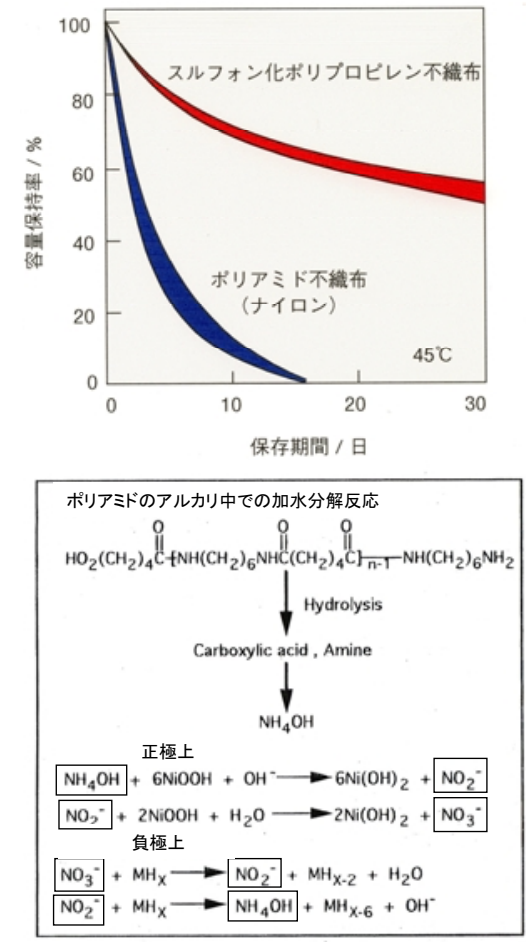

図 3 密閉型ニッケル・水素電池の セパレータが自己放電に及ぼ す影響（生駒ら、1987、1996）

不織布セパレータ中の酸素ガスの透過を容易にするために、 含浸する電解液量を低減しており、充放電サイクルにおい て電極が澎潤したり、発生したガスが安全弁から放出され たりすると、セパレータの電解液涸れ(ドライアウト)が起 こり、これによって電池抵抗が増大して電池寿命となる。 特に、高容量化した密閉電池では活物質の充填密度が高い ため、このドライアウトがサイクル劣化の主な要因となっ ており、セパレータの加圧時の保液性を高めることが重要 とされる。

開発の当初、セパレータには、ニッケル・カドミウム電 池で用いられていたポリアミド(ナイロン)不織布を利用し ていたが、高温 $\left(45^{\circ} \mathrm{C}\right)$ での自己放電が大きく、実用化は困 難と考えられていた。図 3 に示すように、この原因として、 ポリアミドがアルカリ電解液で加水分解してアンモニウム イオンを生成し、これがニッケル正極上で硝酸イオンまで 酸化され、これが再び $\mathrm{MH}$ 負極上で還元されるシャトル 機構が考えられた。そこで、従来のポリアミド系不織布に 代えて、ポリプロピレン (PP) 不織布を熱濃硫酸で処理し て親水化(スルフォン化処理)したところ、ニッケル・カド ミウム電池と同程度まで自己放電が改善されることがわかっ た ${ }^{9,10,12)}$ 。この新規セパレータの開発が、ニッケル水素電池 の商品化に道を開いたといっても過言ではない。

\section{2 セパレータの多様な機能}

水素電池のセパレータが果たしている多様な機能とその 設計指針、影響を受ける電池特性を図 4 にまとめて示す。 (1)高容量化の観点からは、できるだけ薄い膜で、長期の充

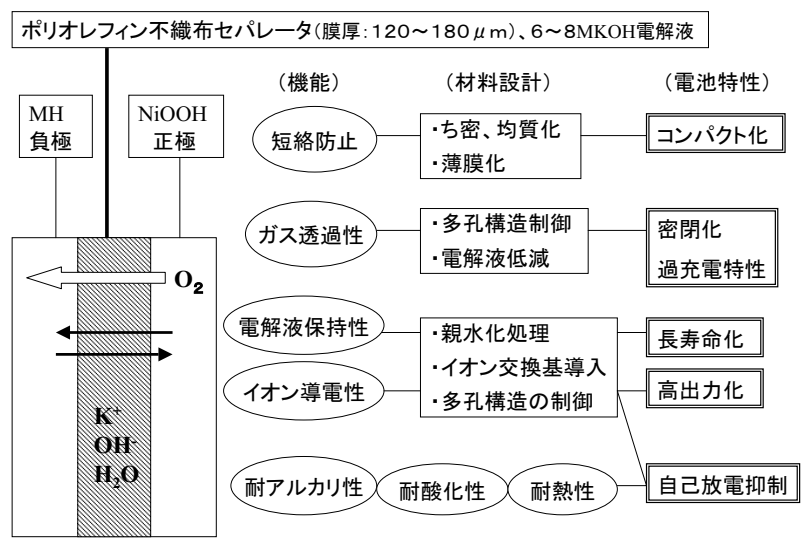

図 4 ニッケル・水素電池用セパレータの役割と電池特性

放電サイクルにおいて短絡防止できる機械的強度が求めら れ、極細の繊維を、緻密かつ均質な不織布に加工する技術 や、高強度な繊維を複合化するなどの開発が進められてい る。(2)密閉化の観点からは、過充電時に正極で発生した酸 素ガスを円滑に負極側に透過させるに十分な多孔構造を確 保するため、不織布が利用されている。(3)サイクル寿命の 観点からは、短絡防止はもちろん、少量の電解液を加圧状 態でもしっかり保持してドライアウトを抑制することが求 められる。(4)高出力化の観点からは、極間抵抗を低減する ために、できるだけ薄い膜で、保液性に優れ、イオン伝導 性に優れることが求められ、スルフォン酸基やカルボン酸 基などのイオン交換基を導入する親水化処理が行われてい る。(5) パレータ素材の観点からは、耐アルカリ性、耐酸 化性、耐熱性などの化学的安定性に優れて、低コスト化が 可能なポリオレフィン系が広く利用されている。

\section{3 セパレータの表面処理法}

ポリオレフィン不織布の表面処理方法が、電池寿命や出 力特性、自己放電特性などに大きな影響を及ぼすことが知 られており、多様な表面処理技術が検討されてきた。(1)湿 式スルフォン化処理は、発煙硫酸や熱濃硫酸中で湿式処理 して繊維内部までスルフォン化処理するものであり、膜強 度の低下が大きく、電解液の吸液性が低いなどの難点はあ るが、自己放電の抑制効果に最も優れており、広く利用さ れている。自己放電の抑制効果については、十分に解明さ れていないが、湿式処理では繊維内部までスルフォン酸基 が導入されやすく、これによって不純物アンモニウムイオ ンの吸着性能が向上するためではないかと考えられてい る ${ }^{17)}$ 。(2)フッ素ガス処理は、フッ素ガスと酸素、亜硫酸ガ スなどで処理して、乾式でスルフォン酸基やカルボン酸基、 水酸基などの官能基を繊維表面に導入するものであり ${ }^{11}$ 、 吸水性がよく、膜強度の低下も少ないなどの利点がある。 ただ、自己放電抑制効果がスルフォン化処理よりも劣る。 (3)グラフト重合処理は、アクリル酸などのビニルモノマー を紫外線や電子線照射によりグラフト重合してカルボン酸 基を瀻維表面に導入するものである ${ }^{13)}$ 。自己放電抑制効果 はフッ素ガス処理よりも若干劣り、また、グラフト重合の 
結合が弱いと電池の充放電サイクルで官能基が脱落しやす くなるなどの問題点が指摘されている。(4)表面をエチレン・ ビニルアルコール共重合体で被覆した鞘芯型繊維を用いて、 水酸基を導入したものでは、親水性には優れているが、自 己放電抑制効果がグラフト重合よりもさらに劣る。(5)表面 コート処理は、不織布表面をイオン交換性樹脂や酸化物で 被覆して親水性を付与したものであり ${ }^{14,15,18)}$ 、膜強度や保 液性の向上に効果があり、電池の長寿命化が図れる利点が あるが、表面コート物質が物理的に脱落する問題がある。 自己放電抑制効果は湿式スルフォン化処理を超えない。

自己放電の評価方法としては、常温で充電後に、 $45^{\circ} \mathrm{C}$ ま たは $60^{\circ} \mathrm{C} て ゙$ 保持して、1 ケ月後の残存容量を調べるのが一 般的であるが、容量保持率はスルフォン化処理膜を $100 \%$ とすると、フッ素ガス処理が $90 \%$ 、グラフト重合処理が 80\%、エチレン・ビニルアルコール共重合体被覆では 70 \%程度となる。すなわち、- $\mathrm{SO}_{3} \mathrm{H}>-\mathrm{COOH}>-\mathrm{OH}$ と 明らかに官能基の酸性度が高い程、高温での自己放電の抑 制効果が大きい傾向が見られる。高温自己放電の機構につ いては明確な結論がでたわけではないが、a)化学結合で 水を強く保持する能力 (これによって水素ガスの拡散を抑 制し、 $60^{\circ} \mathrm{C}$ での自己放電を抑制)、b)水酸化ニッケルに微 量含まれる硝酸イオン、及びこれが還元されて生成したア ンモニウムイオンなどをイオン吸着する能力(これによっ

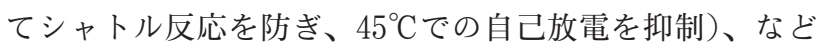
と関係しているのではないかと考えられている。また、自 己放電抑制に優れたセパレータでは、保液性やイオン導電 性にも優れるためサイクル寿命や高率放電特性も向上する 傾向が見られ、最適な親水化処理を施した高性能セパレー 夕の開発が、電池高性能化の鍵を握っている。

\section{4 セパレータの製造法}

セパレータの製造方法は、機械的強度を維持しながら、 細い繊維を均質に不織布に加工し、薄膜化を図っていく方 向で進展している。従来の不織布の製法では、長繊維を乾 式シート化してニードルパンチなどで纎維交絡する乾式法 が主流であったが、均質性や薄膜化に限界があり、最近で は、より緘維径の細い短繊維を用いてょり均質な製膜が可 能な湿式法に移行している。ただ、湿式法では、十分な機 械的強度が得られないため、図 5 に示すように、PP 繊維 の表面を低融点のポリエチレン (PE)で被覆した鞘芯型複 合繊維を用いて熱圧着処理したり、高強度の繊維を混入し たり、PP とエチレン・ビニルアルコール共重合体からな る分割型複合繊維を用いて高圧水流法(スパンレース)で繊 維分割と交絡を同時に行うなどの方法が利用されている。

低コスト化が可能な製法としては、溶融紡系しながら自 己接着してシート化するスパンボンド法があり、機械的強 度にも優れることから一部実用化された。また、ポリマー を高圧で押し出しながら熱風で吹き飛ばし極細繊維をシー ト化するメルトブロー法は均質性には優れているが、機械 的強度に難点があり、実用化には至っていない。

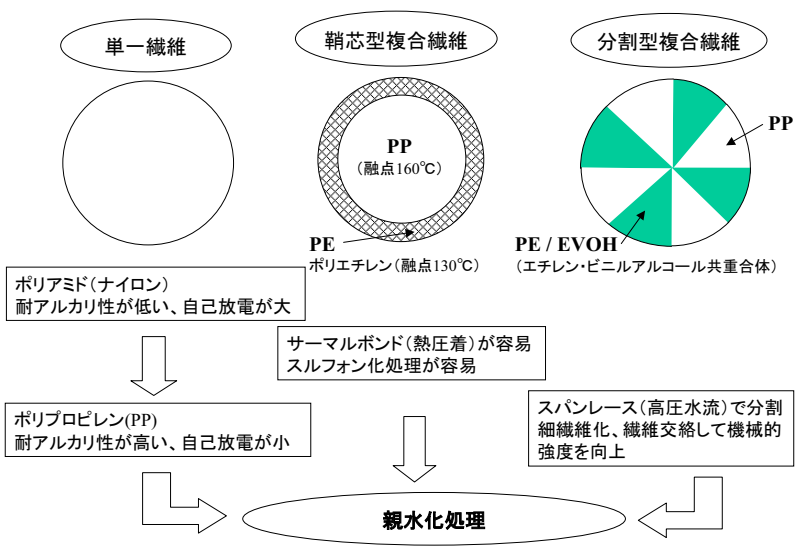

図 5 ニッケル・水素電池用不織布セパレータの繊維素材 之構造

膜強度を維持しながら薄膜化が可能な $\mathrm{PP} / \mathrm{PE}$ 微多孔膜 セパレータについても、その孔径を $0.1 \sim 0.5$ ミクロン程 度に制御してガス透過性を向上させつつ、部分的に表面親 水化処理した薄膜セパレータ(80ミクロン)が開発されて いる ${ }^{19)}$ 。

\section{3. リチゥム電池用セパレータ}

\section{1 反応機構とセパレータ}

この電池は図 6 に示すように、黒鉛負極、コバルト酸リ チウム正極 $\left(\mathrm{LiCoO}_{2}\right) 、$ ポリオレフィン微多孔膜セパレー 夕 (10〜20ミクロン程度) 及び有機電解液 (リチウム塩 $\mathrm{LiPF}_{6}$ とエチレンカーボネートなど)から構成される。充 電すると正極酸化物中のリチウムイオンが移動して黒鉛層 間にインターカレイトされるが、過充電すると電解液の分 解や炭素負極上でのリチウムデンドライトの生成が起こり、 短絡して発火に至るため、厳密な充放電制御と共に多くの 安全機構が備えられている。

特に、微多孔セパレータには、正極と負極の短絡防止機 能とともに、もしも微少短絡が起こった場合は $120^{\circ} \mathrm{C}$ 付近 でポリエチレンが溶融して微多孔を閉じ、電池の内部イン ピーダンスを 3 桁以上増大させ、電池反応の進行を阻止す る電流遮断特性 (シャットダウン機能)が付与されている。 このシャットダウン機能は、 $160^{\circ} \mathrm{C}$ 付近まで維持されるこ とが求められるため、溶融温度以上でも流動性の低い超高

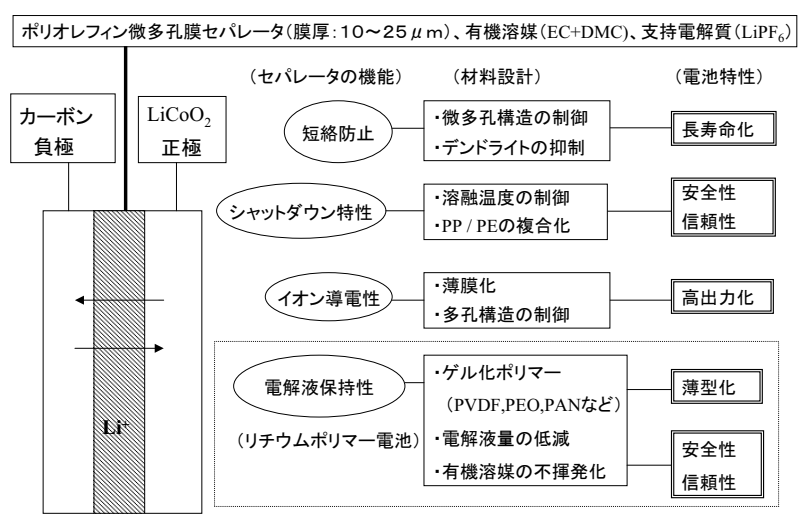

図 6 リチウムイオン電池用セパレータの役割と電池特性 


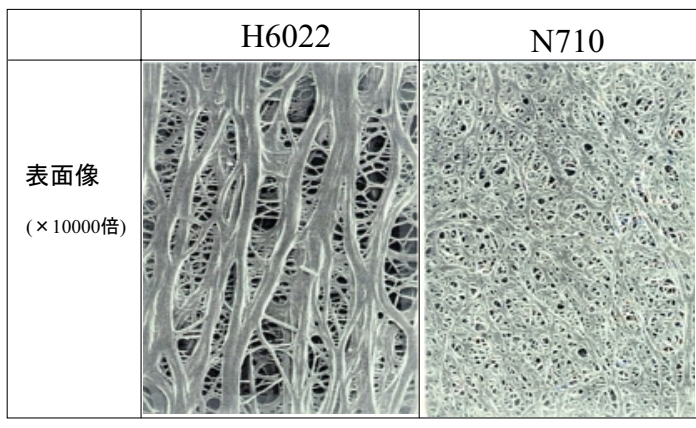

図 7 リチウムイオン電池用微多孔セパレータ (旭化成 ハイポア)

分子量ポリエチレンを用いたり、低融点の PE 膜と融点が $160^{\circ} \mathrm{C}$ 付近の PP 膜の多層複合化などが行われている。ま た、イオン導電性の観点からは、電解液の拡散の妨げにな らない多孔構造を維持しつつ、電極間抵抗を下げるために はできるだけ薄膜化して、かつ、短絡防止することが求め られる。

\section{2 微多孔セパレータの製造方法}

ポリオレフィン微多孔膜の製造方法としては、延伸開孔 法や相分離法が実用化されている(図 7)。(1)延伸開孔法は、 溶融ポリマーをシート化して、さらに熱処理によって積層 ラメラ構造を形成させ、一軸延伸によって結晶界面のはく 離を行うことで、長円形の微多孔を形成するものであり、 開孔径が小さく、異方性が大きいなどの特長がある。(2)相 分離法は、ポリマーと溶剂を加熱溶融してシート化するこ とでミクロ相分離させ、その溶剤を抽出除去しながら一軸 あるいは二軸延伸して孔径と形状の制御を行うものであり、 複雑な形状の微多孔を形成して、異方性が小さく、開孔径 が大きいなどの特長がある。シリカなどの無機微粉体を混 合添加して、これを溶解除去することで、孔径が大きく、 空孔率の高い膜も開発されている。

\section{3 リチゥムポリマー電池}

最近では、有機電解液をゲル化して電解液量の低減と不 揮発化を図ることで安全性を確保しつつ、金属缶に替えて アルミラミネート外装を利用して、薄型化と高容量化を実 現したリチウムポリマー電池の商品化も進められている ${ }^{3)}$ 。 ゲル化ポリマーとしては、ポリフッ化ビニリデン (PVDF) やポリエチレンオキサイド(PEO)、ポリアクリロニトリ ル(PAN)などが用いられる。ゲル化の方法としては、(1) ポリマーを電解液と混合して、電池に注入した後、熱や紫 外線照射で架橋して完全ゲル化する方法、(2)゚リマーを電 極やセパレー夕表面に塗布して扔いて、電解液を注入して ゲル化する方法、(3)ポリマーの微多孔性フィルム (PVDF など)をセパレータとして用いて、電解液を注入してゲル 化する方法、などが開発されている。ポリマー電池では、 電解液を完全ゲル化しないとラミネートのシール部分から の漏液しやすい、ポリマー組成を選ばないと高温での膨潤

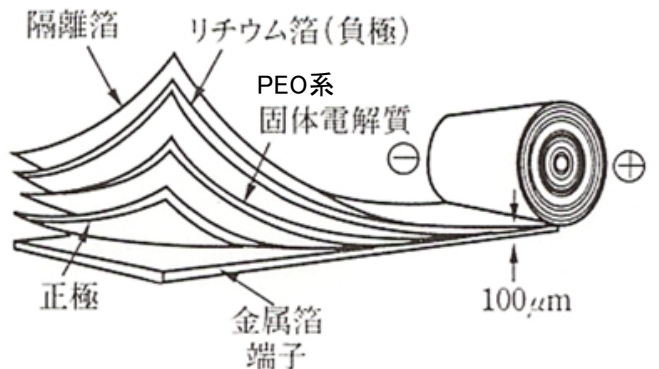

図 8 固体ポリマー型リチウム金属電池の構造

が起きやすい、電解液をゲル化すると低温での放電性能も 低下するなどの問題もあり、広く普及するのは至っていな い。また、従来通りに微多孔セパレー夕を使用して短絡時 のシャットダウン機能を付与しているのが一般的である。

\section{4 完全固体型リチゥムポリマー電池}

セパレー夕と有機電解液に代替して、固体型ポリマー電 解質膜を用いた完全固体型リチウムポリマー電池も、高工 ネルギー密度で、安全性に優れた次世代電池として開発が

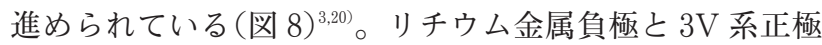
(酸化バナジウムや二酸化マンガンなど)を組み合わせた電 池で実用的な性能が実現されているが、まだ固体電解質の イオン伝導性が低いため、高温作動 $\left(60 \sim 80^{\circ} \mathrm{C}\right)$ が必要となっ ている。バックアップ用電源などの用途で商品化が検討さ れている。ポリマー電解質膜には、リチウム塩を含有した ポリエチレンオキサイド(PEO)などが用いられるが、高 いイオン導電性、薄膜化 (5～20 ミクロ)に耐えうる強度、 $4 \mathrm{~V}$ でも分解しない耐電圧性、リチウム金属に対する安定 性などが求められる。このような要望を満たすために、新 規ポリマーの開発とともに、ポリマーに酸化物粉末を複合 化して強度と導電性を向上させる方法や 21 、高強度ポリマー のマトリックス中に高導電性ポリマーを複合化する方法 ${ }^{222}$ 、 などが提案されている。リチウムイオン電池では、セパレー 夕と電解夜のコストが材料コストの半分以上を占めるため、 これを固体電解質膜で代替できれば、コスト低減の効果は 大きい。

\section{4. 最後に}

セパレー夕は、単なる隔膜の機能ばかりでなく、電池の 高性能化において大変重要な役割を果たしていることがわ かってきた。その高機能化を図るために、材料技術を駆使 しての活発な取り組みが行われているが、高性能化のメ力 ニズムについては不明な点が多い。今後のナノレベルでの 機構解明と材料設計が待たれるところである。さらに、セ パレー夕と電解液の機能を一体化した固体電解質膜は、安 全性と信頼性に優れた次世代高性能二次電池の心臟部とし て期待されている。セパレータは、電池の脇役から主役に なりつつある。セパレー夕製造には、高度な材料技術之高 度な製造技術が必要なため、まだわが国が強い競争力を有 している分野となっており、今後の発展が期待される。 


\section{参考文献}

1）芳尾真幸、小沢昭弥編、リチウムイオン二次電池 材料亡応用、日刊工業新聞 (2000).

2）小久見善八監修、新規二次電池材料の最新技術、シー エムーシー (1997)

3）小山 昇監修、ポリマーバッテリーの最新技術、シー エムーシー (1998)

4）境 哲男、他、水素吸蔵合金—基礎加ら最先端技術 まで、田村英雄監修、第 2 編第 3 章水素吸蔵合金を用 いた二次電池、エヌ・テイ・エス、p.412(1998).

5）丹治博司、河野公一、ポリマーバッテリーの最新技術、 小山 昇監修、第 5 章セパレータ、シーエムーシー (1998).

6）池田宏之助、不織布情報、No. 299、4(1998).

7）押谷政彦、機能材料、シーエムーシー、No. 8、32 (1999).

8）境 哲男、機能紙研究会、No. 38、27(1999）；不織布
情報、No. 317、4(2000).

9）生駒宗久、他、第 28 回電池討論会要旨集、113(1987).

10） M. Ikoma, et al., J. Electrochem. Soc., 143, 1904(1996).

11）盛岡勇次他、第 31 回電池討論会要旨集、55(1990).

12) 福永 浩他、第34 回電池討論会要旨集、241(1993).

13）林田浩孝他、第 36 回電池討論会要旨集、405(1995).

14）西田雅昭他、第38 回電池討論会要旨集、303(1997).

15）安田直史他、電気化学会第 65 回大会講演要旨集、204 (1998).

16）月脚雅彦他、第39 回電池討論会要旨集、87(1998).

17）田中俊雄他、第 41 回電池討論会要旨集、210(1998).

18）長久保周平他、第 41 回電池討論会要旨集、216(1998).

19）近藤孝彦他、第 41 回電池討論会要旨集、218(1998).

20) Y. Xia et.al, J. Electrochem. Soc., 147, 2050(2000).

21) F. Croce, G. B. Appetecchi, L. Persi, and B. Scrosati, Nature, 394, 456(1998).

22）野田和宏、安田壽和、電池技術、15、41(2003). 